\title{
Empirical Analysis of the Impact of Fiscal Policy on Economic Growth of Nigeria
}

\author{
Alex E. Osuala ${ }^{1} \&$ Ebieri Jones ${ }^{2}$ \\ ${ }^{1}$ Department of Banking and Finance, College of Management Sciences, Michael Okpara University of \\ Agriculture, Umudike, Abia State, Nigeria \\ ${ }^{2}$ Department of Accounting, College of Management Sciences, Michael Okpara University of Agriculture, \\ Umudike, Abia State, Nigeria \\ Correspondence: Alex E. Osuala, Department of Banking and Finance, College of Management Sciences, \\ Michael Okpara University of Agriculture, Umudike, PMB 7267, Umuahia, Abia State, Nigeria. Tel: \\ 234-80-3060-6878. E-mail: osuala.alex@mouau.edu.ng
}

Received: March 5, 2014

Accepted: March 13, 2014

Online Published: May 25, 2014

doi:10.5539/ijef.v6n6p203

URL: http://dx.doi.org/10.5539/ijef.v6n6p203

\begin{abstract}
This study provides empirical analysis of the impact of fiscal policy on economic growth in Nigeria. Time series data from 1986 to 2010 relevant to the study were collected from the Central Bank of Nigeria statistical bulletin, Volume 22 and the National Bureau of Statistics. The ordinary least square method of multivariate regression was utilized in analyzing the log-linearized Model. The Augmented Dickey-Fuller unit root test was employed to establish the stationarity of the variables while the General-to-Specific approach to Autoregressive Distributed Lag (ARDL) model was used for testing for the existence of long-run and short-run equilibrium conditions. The findings were that, there is evidence of long run equilibrium relationship between fiscal policy and economic growth in Nigeria during the period studied. The adjusted $\mathrm{R}^{2}$ value of 0.6850 showed that about $68.5 \%$ of the total variation in the real GDP is explained by the independent variables included in the model. Specific fiscal policy variables that have significant and positive impact on economic growth in Nigeria are government recurrent and capital expenditures. Non-oil taxes and government total debts have no significant impact on real GDP. Only capital expenditure has short run equilibrium relationship with economic growth. It is therefore recommended that government should establish a strong fiscal responsibility and transparency system in the fiscal institutions; and tax reforms should be such that would encourage increase in investment and fight corruption. Government debts should be channelled towards provision of critical infrastructure so as to provide the enabling investment environment, while fiscal policy should be complemented with the use of effective monetary policy.
\end{abstract}

Keywords: fiscal policy, economic growth, wald test, Autoregressive Distributed Lag model, Bounds test, Nigeria

\section{Introduction}

It is an established fact that market mechanism cannot solely perform all the economic functions in a country; and as such public policy is required to correct, guide and supplement the market forces. Fiscal and monetary policies are such policies government uses to correct market imperfections and failure. In Nigeria, governments at various times had used these policies to manage the economy with a view to achieving desired macroeconomic objectives such as promoting employment generation, ensuring economic stability, maintaining price stability and balance of payment viability, ensuring exchange rate stability and maintaining stable economic growth. The policy thrust used in manipulating the economy depends on the objectives that need to be achieved at any time period. Government intervention in the economy through fiscal policy has been to manipulate the receipt and expenditure sides of its budget in order to achieve certain national objectives. The reality however is that often, there have been wastages, some spending has been politicized, and there has been high level misappropriation, mismanagement and corruption. Ajisafe and Folorunsho (2002) argued that inappropriate government expenditure, tax policies and large deficits have been responsible for the macroeconomic disequilibrium at varying times in Nigeria. Rena (2011) noted that fiscal governance is strong only when government can deliver their fiscal policy in a sustainable way and are efficiently applied to the 
provision of public goods and services.

The big question however is, has fiscal policy been used effectively to influence growth in the Nigerian economy? Has any fiscal policy measure been effective towards the achievement of sustainable growth in the economy? Proffering answers to the above questions and empirically evaluating the impact of fiscal policy on Nigeria's economic growth is the main objective of this study.

\section{Literature Review}

\subsection{Conceptual Framework}

Buhari (1993) argued that fiscal policy is concerned with deliberate actions which the government of a country take in the area spending money and or levying taxes with the objective of influencing macroeconomic variables such as the level of national income or output, the employment level, aggregate demand level, the general level of prices etc in a desired direction. Bhatia (2008) noted that fiscal policy consists of steps and measures which the government takes both on the revenue and expenditure sides of its budget and that it is the aggregate effects of government expenditures and taxation on income, production and employment. Dwivedi (2009) stated that it is government's programme of taxation, expenditure and other financial operations to achieve certain national goals. He posited that whatever the objectives and the order of priorities, the two basic instruments of fiscal policy used to achieve social goals are taxation and public expenditure According to Jhingan (1997), he opined that fiscal policy refer to government actions affecting its receipts and expenditures which we ordinarily taken as measured by the government's net receipts, its surplus or deficit, Again, Ijeh (2008) refer to fiscal policy as government action plan concerning how to raise funds and disburse funds. He further posited that it is the use of government revenue and expenditure programmes to affect the economy in a way to produce desirable effect such as achieving full employment, general good price level, aggregate demand and economic growth and development. He noted that the instruments of fiscal policy are taxation, government expenditure, government budget, public debts and subsidy.

Government intervention in the economy through its fiscal policy is usually enunciated in its budget. Government tries to manipulate the fiscal policy instruments to stabilize the economy and achieve a desired level of economic growth. Bhatia (2008) posited that when an economy is stabilized, investment decisions are more favourably effected as consumption expenditure does not fall below certain minimum level and forms a cushion against economic contraction.

\subsection{Fiscal Policy in Nigeria}

Nigeria's fiscal intervention in recent years has been to stimulate economic recovery from the negative effects of the global economic and financial crisis. It has embarked on increased spending on priority sectors to provide an enabling environment needed to accelerate sustainable economic growth and development driven by the private sector. The key priority sectors and areas where funds are mainly expended are critical infrastructure, human capital development, land reforms, food security, physical security and maintenance of law and order, the Niger Delta area, power sector (to enhance electricity generation, transmission and distribution; expansion, management and maintenance of existing and new power plants), provision of credit facilities to farmers, review of existing tariffs and provision of fiscal incentive to enhance productivity in the real sector and provide alternative transportation of goods and services through investment in upgrading the existing railway network and dredging the waterways (CBN, 2010).

The federal Government expenditure profile from 1986 to 2010 on the average has been in the region of $61 \%$ for recurrent expenditure as against $39 \%$ for capital expenditure of the overall expenditure framework. Included in its recurrent expenditure other than personnel and various administrative costs are interest payments on debts servicing and other such transfers and extra budgetary items. The ratio of recurrent expenditure on the overall government expenditure framework in Nigeria's annual budget has always been subject of debate in the National Assembly. Only recently, the 2014 proposed budget has $74 \%$ of the total proposed budget expenditure earmarked for recurrent expenditure while $26 \%$ was for capital expenditure.

The Federal government capital expenditure framework has been hinged on administration, economic services, social and community services and transfers (i.e. interest and capital repayment on loans). Due to the pressure from borrowings, transfers was apportioned a larger allocation of capital expenditure on an average of up to $43.83 \%$, social and community services $7.77 \%$, economic services $34.68 \%$ and administrative $13.72 \%$ from 1986 to 1999 while from 2000 to 2010 transfers took the least with $6.9 \%$, social and community services $13.54 \%$, economic services $50.35 \%$ and administrative $29.22 \%$. However, considering the period under study from 1986 to 2010 , the average apportionment of capital expenditure were administrative $20.54 \%$, economic services 
$41.58 \%$, social and community services $10.30 \%$ and transfers $27.58 \%$. This implies that as the burden of debt reduces, capital expenditure on transfers receives less allocation of funds while emphasis is laid on economic services such as financing of critical infrastructure so as to enhance an enabling business environment.

In Nigeria, tax as fiscal policy instrument are used for achieving different objectives such as raising revenue for the government, redistribution of income, efficient allocation of resources (through the provision of social goods and services) encouraging the propensity to save, encouraging investment, stimulate certain sectors of the economy, discouraging the production of certain goods, attracting foreign direct investment etc. The choice and direction of tax policies depend on the intendment of government to influence these competing objectives.

The enactment of the Finance (Miscellaneous Taxation Provisions) Act No.3 of 1993 and decree 104 of 1993 brought major changes in the Nigerian tax system. While Act No.3 of 1993 reviewed the composition of the Federal Board Inland Revenue (FBIR) and also established the Federal Inland Revenue Service (FIRS), decree 104 amongst others reviewed the functions of the Joint Tax Board (JTB). Value added tax (VAT) was introduced through decree No. 102 of 1993 (as amended) but took effect in 1994 to replace Sales tax decree No. 7 of 1986 which hitherto was imposed on all goods manufactured in the country and imported goods. Value added tax is imposed on certain goods and services and charged at the rate of $5 \%$ on the value of all taxable goods and services. The decree specified certain goods and services to be exempted for the tax such as all exported goods, medical and pharmaceutical products, products meant for babies, basic food items, commercial vehicles and their spare parts, books and other educational materials, fertilizer, farming machines, agricultural products, farming transportation equipments, veterinary medicines, magazines and newspapers. The services exempted are all services that are exported, medical services, plays and performances that are run by educational institutions for educational purposes and services that are provided by the community banks, mortgage organisations and the peoples' bank. (Tax laws in Nigeria, 2011). In spite of the above changes that took place in the Nigerian tax system, the country had hitherto often experienced initially lofty policies found not practicable in view of ambiguity in policy objectives, inefficiency of fiscal institutions, infractions and abuses.

According to the FIRS (2012), the pre-2004 structure was inadequate to achieve the objectives of the tax reforms. It asserted that the structure not only bred inefficiency, indiscipline and fraud, it was also chaotic that it sorely limited the revenues that were derived from taxation all over the country. In 2004, the first step was to integrate the collection as a function of ICT and the Planning, Research and Statistics (PRS) division while the VAT and the Tax Area office were collapsed into one integrated tax offices (ITOs). The reform agenda caused the re-engineering of the Federal Inland Revenue Service (FIRS) organizational structure which led to the identification of seven strategic areas to drive the institution in enhancing performance namely;

a. Funding/autonomy.

b. Capacity building (improved structure and staffing), process re-engineering (human resources, finance and procurement processes.

c. Audit oil and gas/large tax payers.

d. Taxpayer education.

e. Strengthening investigation and enforcement.

f. Automate tax collection.

The FIRS (2012) stated that the overall goal of these strategic measures was to foster the increase in collection on a year-to-year basis by at least 25 percent relative to the 2004 level. In 2004, the reform the overriding consideration and focus was on the need to shift emphasis from oil to more sustainable source of funding in the area of non-oil revenue. Of particular importance is the need to develop the non oil tax segment and increase its overall and enabling political and legal environments. The changes that have occurred in the tax system since 2004 cut across organizational restructuring of the Federal and State authorities, the enactment of the National Tax Policy, funding, legislation, taxpayer education, dispute resolution mechanism, taxpayer registration, human capacity building, automation of key processes, refund mechanism etc.

In 2007, financial and administrative autonomy was granted the Federal Inland Revenue Service through the passage of the Federal Inland Revenue Service (Establishment) Act 2007. This act granted the FIRS autonomy from the civil service bureaucracy, chiefly in the area of funding and human resource management and also established the Tax Appeal Tribunal (which was inaugurated in February 5, 2010) to settle disputes arising from the operations of the Act (FIRS, 2012).

The tax reforms especially on strengthening and re-engineering the institutional framework to enhance its 
performance have brought notable increases in tax revenue generation as reflected in percentage increases of $221.4 \%, 236.2 \%, 292.1 \%$ and $337.2 \%$ in 2007, 2008, 2009 and 2010 respectively over the 2004 non-oil tax revenue figures after the implementation of the reforms particularly with the granting of autonomy to the Federal Inland Revenue Service (FIRS), the operational arm of the Federal Board of Inland Revenue (FBIR). The main thrust of the reforms is to enhance increase in tax revenue generation particularly the non-oil revenue by improving on the collection processes and reduce tax evasion and avoidance. However, whether these increases in tax revenue had impacted on economic growth is subject to empirical evidence.

According to Alli (2009), the objectives of the tax reforms in Nigeria are:

a. To bridge the gap between the country's development needs and the funding of the needs.

b. To enhance taxation as a fiscal policy instrument.

c. To improve on the level of tax revenue generation from non-oil activities in relation to revenue derived from oil activities.

d. To facilitate efforts at constantly reviewing the tax laws to reduce and manage tax evasion and avoidance.

e. To achieve improved service delivery by the tax institutions to the public.

f. To improve the tax administration to make it more efficient, responsive, reliable, skilful and taxpayers friendly; and

g. To achieve other fiscal objectives.

With the launch of the National Economic Empowerment Development Strategy (NEEDS), the tax system became a critical part of the reform agenda. This led to the initiation and formulation of the National tax policy with the following economic thrust:

a. Stimulating the growth of the Nigerian economy by using tax revenues to develop basic infrastructure such as power, roads, transportation and such other infrastructure which will stimulate economic growth.

b. Direct stimulation of certain sectors of the economy which are identified to be important for the creation of employment opportunities for Nigerians.

c. Regulating and strengthening financial and economic structures and for correcting market imbalances and economic distortions.

d. Income redistribution such that tax earned from high income earners are used for the provision of infrastructure for the lowest income earners. Taxes shall act as a means to create a social security net and,

e. Stimulating domestic and foreign investment. (FIRS 2012).

An analysis of the fiscal operations by the Nigerian government reveals that there was a growing debt from both domestic and external sources ostensibly to augment shortfalls in revenue for developmental purposes except for 1996 and 1997 where decrease by $13.9 \%$ and $16.9 \%$ respectively was experienced below that of 1995 . External borrowing will only be beneficial where the funds results in a higher returns than the cost of borrowing. Obviously, Nigeria's external borrowing became a huge burden on the economy and at a time, the external debts was at a startling proportion of up to $\$ 33 \mathrm{~b}$ to the extent that Nigeria was regarded as the most debtor nation in Africa. The country was however granted debt relief by year 2005 to the tune of $\$ 18 b$ and a subsequent $\$ 12 b$. Bakare (2010) claimed that despite the debt forgiveness to the tune of $\$ 18 \mathrm{~b}$ received by the Nigerian from Paris club since year 2005 and the subsequent payment of $\$ 12 b$ to offset the remaining debt, there was no evidence of accelerated pace of growth and development of the country. Domestic debt was also increasing severely through the issue of treasury bills, certificates and bonds, development stock, the banking sector and from non bank public.

\subsection{Empirical Review}

Babalola and Aminu (2011) in their study of fiscal policy and economic growth relationship in Nigeria (1977-2009) using the Engle-Granger approach to Co-integration test, stated that productive expenditure was found to be statistically significant. They utilized logarithms of real gross domestic product as proxy for economic growth representing the dependent variable while the independent variables were the logarithms of productive government consumption expenditure (defined as expenditure on health, education, and economic services), unproductive government consumption expenditure (defined as total recurrent expenditure less recurrent expenditure on health, education and economic services), direct income tax, and capital expenditure. Appah (2010) in his study of the relationship between fiscal policy and economic growth in Nigeria (1991-2005) utilizing multiple regression analysis, adopting gross domestic product as proxy for economic growth and tax 
revenue, government debt, government recurrent expenditure, government capital expenditure, government recurrent expenditure budget and government capital expenditure budget as the explanatory variables argued that significant relationship exist between fiscal policy variables jointly and economic growth and that the specific variables contributing to the GDP are government recurrent and capital expenditures. Similarly, Medee and Nendee (2011) in their study on econometric analysis of the impact of fiscal policy variables on Nigeria's economic growth (1970-2009) using gross domestic product as the dependent variable and Federal government expenditure, Federal government revenue, inflation rate and capital inflow as the regressors and by adopting arcane method of Vector autoregression and error correction mechanism techniques argued that there exists long run equilibrium relationship between fiscal policy variables and economic growth in Nigeria.

Omitogun and Ayinla (2007) in their study of fiscal policy and Nigerian economy (1981-2004) using Solow growth model estimated with the ordinary least square method claimed that fiscal policy has not been effective in the area of promoting sustainable economic growth. They used gross domestic product as proxy for economic growth representing the dependent variable while fiscal deficit ratio, debt financed deficits and money printing financed deficits were used as explanatory variables.

\subsection{Fiscal Policy and Economic Growth}

The International Monetary Fund (2009) and CBN (2010) stated that economic growth is the increase in the amount of the goods and services produced in an economy over time. It is conventionally measured as the percent rate of increase in real gross domestic product, or real GDP (RGDP). Growth is usually calculated in real term i.e. inflation- adjusted terms, in order to net out the effect of inflation on the price of the goods and services produced. The drivers of economic growth in an economy as posited by Dwivedi (2008) are the quality of the labour force, natural resources, capital formation, technological development and political and social factors while Riley (2012) noted that the determinants are growth in physical capital stock; growth in the size of active labour force available for production; growth in the quality of human capital; technological progress and innovation; institutions including stable democracy, maintaining rule of law and macroeconomic stability; and rising demand for goods and services either led by domestic demand or from external trade. Therefore, for fiscal policy to impact on economic growth, the management of the fiscal instruments will be directed to affect each or some of the drivers of growth as the case may be so as to impact on the overall growth of the economy.

The measure and potency of fiscal policy to achieve economic growth will inter alia depend on the transparency and accountability of the fiscal institutions, appropriate combination of fiscal strategy and suitable mix of monetary policy, political stability, socio-political inclination of the society, state of nature of the economy and response of the market forces. The practicality of fiscal policy through variations of its instruments to impact on economic growth will depend on the state of nature of the economy at a particular period of time as the management and adaptability of the instruments during each of the state of nature will vary from one period to another. The fiscal policy thrust will be different at each of the economic cycles since at each cycle, the economy will be at different level of equilibrium position.

A variation in the fiscal instruments by way of increases in government expenditure through deficit budgeting and reduction in taxes will positively affect aggregate demand, employment, output and income within the economy. This is referred to as expansionary fiscal policy. However, if government desire to reduce aggregate demand, the above measure would be reversed. This is referred to as contractionary fiscal policy. Musgrave and Musgrave (2004) noted that budget policy affects the division of total output between consumption and capital formation and thereby the rate of economic growth. Nevertheless, increase in government expenditures through deficit financing by way of issue of treasury bills, certificates or bonds or tax cut will cause crowding effect of private investments. Jhingan (1997) argued that government can also use discretionary fiscal policy by changing taxes and keeping its expenditure constant, changing its expenditure with constant taxes and vary both expenditure and taxes simultaneously.

\section{Methodology}

\subsection{Method of Data Collection}

Time series data from 1986 to 2010 of the related variables were collected from the Central Bank of Nigeria (2010) statistical bulletin volume 21 and National bureau of statistics. The variables are real gross domestic product, Federal government recurrent expenditure, Federal government capital expenditure non oil taxes and total debts of the Federal government.

\subsection{Model Specification and Operational Definition of Variables}

The model specification will be based on the theory that fiscal policy impact on the economic growth of Nigeria. 
Specifically, arising from the evidences in the empirical studies reviewed in section 2.3 above, we adopted the model as stated by Appah (2010) but with modifications. Consequently, the functional form of the model specification will be:

$$
R G D P=f(N T R, R E X, C E X, T D)
$$

Explicitly, equation 1 can be written as:

$$
R G D P_{t}=\beta_{0}+\beta_{1} N T R_{t}+\beta_{2} R E X_{t}+\beta_{3} C E X_{t}+\beta_{4} T D_{t}+u_{t}
$$

Log-linearizing equation 2 above, we obtain equation 3 .

$$
\log R G D P_{t}=\beta_{0}+\beta_{1} \log N T R_{t}+\beta_{2} \log R E X_{t}+\beta_{3} \log C E X_{t}+\beta_{4} \log T D_{t}+u_{t}
$$

Where:

$R G D P=$ Real Gross Domestic Product (proxy for economic growth);

$N T R=$ Federal government Non-oil Taxes;

$R E X=$ Federal government recurrent expenditure;

$C E X=$ Federal government capital expenditure;

$T D=$ Federal government total debt defined as domestic and foreign borrowings.

Where $\beta_{0}=\mathrm{Y}$-intercept term. This gives the mean or average value of RGDP when all the explanatory variables included in the model put at zero.

And $\beta_{1}, \beta_{2}, \beta_{3}, \beta_{4}$, are parameters known as partial regression coefficient or partial slope coefficients (Gujarati \& Porter, 2009; Gujarati, 2006; Osuala, 2010).

$U_{t}=$ the stochastic term or the unexplained variation in RGDP. Sweeney et al. (2006) stated that it accounts for the variability in the dependent variable that cannot be explained by the linear effect of all the independent variables in the model.

$t=$ the time period.

Log = natural logarithm.

\subsection{Data Estimation Techniques}

The Ordinary Least Squares (OLS)-based Autoregressive Distributed Lag (ARDL) / Bounds testing approach was used for testing the long-run co-integrating relationship among the time series variables. The Bounds testing methodology developed by Pesaran and Shin (1999) has some advantage over conventional co-integration testing approaches because it can be used with a mixture of $\mathrm{I}(0)$ and $\mathrm{I}(1)$ data, and again, it involves just a single-equation set-up, making it simple to implement and interpret.

Generically, the "unrestricted" error correction model (ECM) of Pesaran and Shin of equation (3) is given as shown in equation (4):

$$
\Delta \ln Y_{t}=\alpha_{0 y}+\sum_{i=1}^{n} \alpha_{y i} \Delta Y_{t-1}+\sum_{i=1}^{n} \alpha_{y i} \Delta X_{i t-1}+\beta_{1 y} \ln Y_{i t-1}+\beta_{2 y} \ln X_{i t-1}+e_{1 t}
$$

where $\Delta$ is the first difference operator, the $\alpha$ are the short-run dynamic coefficients of the model, and $\beta$ are the long-run effects.

As a preliminary step in ARDL/Bound testing, we employed the Augumented Dickey Fully Unit root test to confirm the order of integration of the time series variables. This is necessary because the presence of an order of integration higher than I(1) such as I(2) will invalidate the use of Pesaran and Shin computed F-statistics which is based on the assumption that the underlying variables must be either $\mathrm{I}(0)$ or $\mathrm{I}(1)$ or mutually integrated. The General-to-Specific approach to co-integration was adopted, in which the non-significant variables in the model are progressively and systematically eliminated until all the remaining variables are found statistically significant at the desired level of significance.

\subsubsection{Unit Root Test}

The unit root or stationarity test was carried out using the Augmented Dickey-Fuller test.

The following generic equation is used to check the stationarity of the time series data used in the study.

$$
\Delta Y_{t}=\beta_{0}+\beta_{1} t+\partial Y_{t-1}+\alpha \sum_{t=1}^{m} \Delta Y_{t-1}+\varepsilon_{t}
$$


where $\varepsilon_{t}$ is white noise error term and $\Delta Y_{t-1}=Y_{t-1}-Y_{t-2}$; and $\Delta Y_{t-2}=Y_{t-2}-Y_{t-3}$; and where $\partial$ is the coefficient of the lagged length, $Y_{t-1}$.

In general, $\partial$, the coefficient of the lagged length $Y_{t-1}$ is expected to be negative, and the estimated $\mathrm{t}$ statistic will have a negative sign. Therefore, a large negative $t$ value is generally an indication of stationarity.

The null hypothesis is HO: $\delta=0$ (i.e., there is a unit root or the time series is non-stationary or it has a stochastic trend).

The alternative hypothesis is HI: $\delta<0$ (i.e., the time series is stationary, possibly around a deterministic trend).

\subsubsection{Wald Test}

This is used to test the joint significance of the variables before dropping any of the independent variables. It is an F- test for the significance of all the variables in the model based on the hypothesis below:

The null hypothesis is:

$\mathrm{H} 0: \beta 1=\beta 2=\beta 3=\beta 4=0$ (i.e., there is no long run relationship between the variables.)

The alternative hypothesis is:

$\mathrm{HI}: \beta i \neq 0$ (where $\beta \mathbf{i}=\beta 1, \beta 2, \beta 3$ and $\beta 4$ ).

\section{Results and Discusions}

As explained in section 3, unit root test was done to establish the order of integration. The result of the test is summarized in Table 1.

Table 1. Augmented Dickey Fuller (ADF) unit root test

\begin{tabular}{lllll}
\hline \multirow{2}{*}{ Variable } & \multicolumn{4}{c}{ ADF Statistics } \\
\cline { 2 - 5 } & Level & First Difference & Lag Length & Order of Integration \\
\hline $\log ($ RGDP $)$ & 1.315304 & $-3.031484^{* *}$ & 4 & $\mathrm{I}(1)$ \\
$\log (\mathrm{NTR})$ & -1.518264 & $-6.313526^{* * *}$ & 4 & $\mathrm{I}(1)$ \\
$\log (\mathrm{REX})$ & -0.734664 & $-5.957306^{* * *}$ & 4 & $\mathrm{I}(1)$ \\
$\log (\mathrm{CEX})$ & -1.745015 & $-6.117272^{* * *}$ & 4 & $\mathrm{I}(1)$ \\
$\log (\mathrm{TD})$ & $--3.030699^{* *}$ & - & 4 & $\mathrm{I}(0)$ \\
\hline
\end{tabular}

Note. $(*),(* *)$ and $(* * *)$ indicate significant at $1 \%, 5 \%$ and $10 \%$ respectively. All the variables are log linearised.

Based on the above result of the Augmented Dickey-Fuller unit root test, all the variables are integrated of order 1(1) except logTD which is integrated of order 1(0). Real gross domestic product and Federal government total debts are significant at 5\% level of significance while Federal government non-oil taxes, it's recurrent and capital expenditures are significant at $10 \%$ level of significance. This means that the null hypothesis will not be accepted. We therefore conclude that the time series collected are all stationary.

Table 2. Wald test result

\begin{tabular}{lccc}
\hline $\begin{array}{l}\text { Equation: Untitled } \\
\text { Test Statistic }\end{array}$ & Value & Df & Probability \\
\hline F-statistic & 7.279396 & $(5,10)$ & 0.0041 \\
Chi-square & 36.39698 & 5 & 0.0000 \\
Null Hypothesis: $\mathrm{C}(1)=\mathrm{C}(2)=\mathrm{C}(3)=\mathrm{C}(4)=\mathrm{C}(5)=0$ & \\
Null Hypothesis Summary: & & \\
Normalized Restriction $(=0)$ & Value & Std. Err. \\
C(1) & -0.481193 & 0.147074 \\
$\mathrm{C}(2)$ & 0.012718 & 0.035965 \\
$\mathrm{C}(3)$ & -0.050701 & 0.021473 \\
$\mathrm{C}(4)$ & -0.121429 & 0.028705 \\
$\mathrm{C}(5)$ & 0.008201 & 0.008527 \\
\hline
\end{tabular}

Note. Restrictions are linear in coefficients. 
The calculated F-statistics is statistically significant at $5 \%$ level at $\mathrm{K}=4$, thus indicating the existence of long-run relationship between the economic variables. This implies that collectively or jointly, the independent variables are significant, thus suggesting the existence of a long-run relationship between the variables.

Therefore we proceed with the General-to-specific ARDL approach to co-integration.

Table 3. General-to-specific ARDL approach to co-integration

\begin{tabular}{|c|c|c|c|c|}
\hline \multicolumn{5}{|c|}{ Dependent Variable: D(RGDP) } \\
\hline \multicolumn{5}{|c|}{ Method: Least Squares } \\
\hline \multicolumn{5}{|c|}{ Date: 08/01/13 Time: 09:41 } \\
\hline \multicolumn{5}{|c|}{ Sample (adjusted): 323} \\
\hline \multicolumn{5}{|c|}{ Included observations: 21 after adjustments } \\
\hline Variable & Coefficient & Std. Error & $\mathrm{t}$-Statistic & Prob. \\
\hline RGDP(-1) & -0.526270 & 0.127545 & -4.126156 & 0.0009 \\
\hline $\operatorname{REX}(-1)$ & -0.028094 & 0.013231 & -2.123270 & 0.0508 \\
\hline $\operatorname{CEX}(-1)$ & -0.116514 & 0.025079 & -4.645804 & 0.0003 \\
\hline $\mathrm{D}(\mathrm{CEX}(-1))$ & 0.062499 & 0.023695 & 2.637634 & 0.0186 \\
\hline $\mathrm{C}$ & 3.345351 & 0.733131 & 4.563103 & 0.0004 \\
\hline @TREND & 0.026777 & 0.004711 & 5.683621 & 0.0000 \\
\hline R-squared & 0.763488 & F-statistic & & 9.684324 \\
\hline \multicolumn{2}{|c|}{ Adjusted R-squared 0.684650} & \multicolumn{2}{|c|}{ Prob(F-statistic) } & 0.000276 \\
\hline
\end{tabular}

From the above result, the adjusted $\mathrm{R}^{2}$ that is, the coefficient of multiple determination showed that $68.5 \%$ of the total variation in the real GDP is explained by the independent variables included in the model. In order words, $68.5 \%$ of the total variation in the real GDP (economic growth) is as a result of variation in Federal government non-oil taxes, Federal government recurrent expenditure, Federal government capital expenditure and total debts of the Federal government of Nigeria. Collectively, there is trend between the variables which implies that an increase in the fiscal policy variables will increase economic growth while a decrease will also decrease economic growth.

The $\mathrm{p}$ value of the F-statistics is 0.0003 which is sufficiently low and we therefore conclude that there is long run equilibrium relationship between fiscal policy and economic growth in Nigeria. The result also revealed that only Federal government recurrent and capital expenditures are significant at $5 \%$ and $1 \%$ levels respectively. This implies that only recurrent and capital expenditures as fiscal policy measures have long run equilibrium relationship with economic growth of Nigeria. The long run multiplier between recurrent expenditure and real GDP is $-(-0.526270 /-0.028094)=-18.73$. This implies that in the long run, a decrease of 1 percent in recurrent expenditure will lead to a decrease of $18.73 \%$ in real GDP. Again, the long run multiplier between capital expenditure will be -4.52 which implies that in the long run, a $1 \%$ decrease in capital expenditure will result in a decrease of $4.52 \%$ in real GDP. Amongst the fiscal policy instruments, only capital expenditure has short run equilibrium relationship with economic growth. The result implies that non-oil taxes and total debts are not significant on their own as fiscal policy instruments on the economic growth of Nigeria. The result is in consonance with that of Appah (2010) and Medee and Nenbee (2011).

\section{Conclusion and Recommendations}

The ordinary least square method of multivariate regression was utilized, adopting Log Linear Model in analysing the relationship between economic growth and fiscal policy in Nigeria. The General-to-Specific Approach to Autoregressive Distributed lag (ARDL) / Bounds test method to Co-integration was used to establish the existence of long-run and short-run relationship between the economic variables. The findings were that about $68.5 \%$ of the total variation in real gross domestic product was as a result of variation in the independent variables included in the model and that there is evidence of long run equilibrium relationship between fiscal policy and economic growth in Nigeria. Specific fiscal policy variables that have significant impact on economic growth in Nigeria are government recurrent and capital expenditures while non-oil taxes and government total debts have no significant relationship. Only capital expenditure has short run equilibrium relationship with economic growth. It is therefore recommended that government should establish a strong fiscal responsibility and transparency system in the country, adopt tax reforms that would encourage increase in investment, fight corruption, and ensure that Government debts are used to invest in critical infrastructure so as 
to provide the enabling investment environment. Besides, fiscal policy should be complemented with the use of a mix of effective monetary policy and maintain the rule of law to foster stability in the economy.

\section{References}

Ajisafe, R. A., \& Folorunsho, B. A. (2002). The relative effectiveness of fiscal and monetary policies in macroeconomic management of Nigeria. The African Economic and Business Review, 3(1), 23-40.

Alli, B. D. (2009). Managing the tax reform process in Nigeria. Niger Account, 42(1), 45-51.

Appah, E. (2010). The Relationship between fiscal policy and Economic growth in Nigeria (1991-2005). International Journal of Economic Development Research and Investment, 12.

Babalola, S. J., \& Aminu, U. (2011). Fiscal policy and economic growth relationship in Nigeria. International Journal of Business and Social Sciences, 2(17).

Bakare, A. S. (2010). Debt Forgiveness and its impact on the growth of Nigeria economy: An empirical study. Pakistan Journal of Social Sciences, 7(2), 34-39. http://dx.doi.org/10.3923/pjssci.2010.34.39

Bhatia, H. L. (2008). Public Finance (26th ed.). Jangpura, New Delhi: Vikas Publishing House PVT 1td.

Buhari, A. L. (1993). Straight to Point ICAN/Polytechnic Public Finance. University of Ilorin, Nigeria: Unillorin press.

Central Bank of Nigeria. (2010). Annual report and financial statements. Statistical Bulletin, 21.

Dwivedi, D. N. (2008). Managerial Economics (7th ed.). Jangpura New Delhi: Vikas Publishing House PVT ltd.

FIRS. (1993). Federal inland Revenue Services. Retrieved from http://www.firs.gov.ng

FIRS. (2012). Taxation reform in democratic Nigeria.

Gujarati, D. N. (2006). Essentials of Econometrics (3rd ed.). Boston: Mcgraw-hill International Edition.

Gujarati, D. N., \& Porter, D. C. (2009). Basic Econometrics (5th ed.). Boston: Mcgraw Hill International Edition.

Ijeh, M. C. (2008). Public Finance in Focus. Justice Jeco Press \& Publishers Ltd.

International Monetary Fund. (2009). Deflation, economic growth, BOP. Celebrating the spirit of small enterprise.

Jhingan, M. L. (1997). Macro-Economic Theory (11th ed.). Delhi: Vrinda Publication(P) Ltd.

Medee, P. N., \& Nenbee, S. G. (2011). Econometric analysis of the impact of fiscal policy variables on Nigeria's economic growth (1970-2009). International Journal of Economic Development, Research and Investment, 2(1), 171-183.

Musgrave, R., \& Musgrave, P. B. (2004). Public finance in theory and practice (5th ed.). New Delhi: Tata Mcgraw Hill Education Private ltd.

Omitogun, O., \& Ayinla, T. A. (2007). Fiscal policy and Nigerian economic growth. Journal of Research in National Development, 5(2).

Osuala, A. E. (2010). Econometrics, theory and problems. Nigeria: Toni Prints services, Aba.

Pesaran, M. H., \& Shin, Y. (1999). An autoregressive distributed lag modeling approach to co-integration analysis, Chapter 11. In S. Strom (Ed.), Economic Theory in the 20th century. Cambrige: The Ragnar Frisch centennial symposium Cambrige University press. http://dx.doi.org/10.1017/CCOL521633230.011

Rena, R. (2011). Public Finance and Taxation. Windhoek centre for lifelong learning, Polytechnic of Nambia.

Sweeney, D. L., Williams, T. A., \& Anderson, D. R. (2006). Fundamentals of Business Statistics. International Student Edition Thomson South-Western.

Tax laws in Nigeria. (2011).

\section{Copyrights}

Copyright for this article is retained by the author(s), with first publication rights granted to the journal.

This is an open-access article distributed under the terms and conditions of the Creative Commons Attribution license (http://creativecommons.org/licenses/by/3.0/). 